Old Dominion University

ODU Digital Commons

English Faculty Publications

English

1995

\title{
A Previously Unremarked Circulating Library: John Roson and the Role of Circulating-Library Proprietors as Publishers in Eighteenth-Century Britain
}

Edward Jacobs

Old Dominion University, ejacobs@odu.edu

Follow this and additional works at: https://digitalcommons.odu.edu/english_fac_pubs

Part of the Cultural History Commons, and the Literature in English, British Isles Commons

\section{Repository Citation}

Jacobs, Edward, "A Previously Unremarked Circulating Library: John Roson and the Role of Circulating-Library Proprietors as Publishers in Eighteenth-Century Britain" (1995). English Faculty Publications. 24.

https://digitalcommons.odu.edu/english_fac_pubs/24

\section{Original Publication Citation}

Jacobs, E. (1995). A previously unremarked circulating library: John Roson and the role of circulating-library proprietors as publishers in eighteenth-century Britain. Papers of the Bibliographical Society of America, 89(1), 61-71.

This Article is brought to you for free and open access by the English at ODU Digital Commons. It has been accepted for inclusion in English Faculty Publications by an authorized administrator of ODU Digital Commons. For more information, please contact digitalcommons@odu.edu. 
Articles from 2013 and after

are now only accessible on

the Chicago Journals website at

JOURNALS.UGHICABO.EDU

\section{Bibliographical Society of America}

A Previously Unremarked Circulating Library: John Roson and the Role of CirculatingLibrary Proprietors as Publishers in Eighteenth-Century Britain

Authors(s): Edward Jacobs

Source: The Papers of the Bibliographical Society of America, Vol. 89, No. 1 (MARCH 1995), pp. 61-71

Published by: The University of Chicago Press on behalf of the Bibliographical Society of America

Stable URL: http://www.jstor.org/stable/24304635

Accessed: 25-03-2016 18:12 UTC

\section{REFERENCES}

Linked references are available on JSTOR for this article: http://www.jstor.org/stable/24304635?seq=1\&cid=pdf-reference\#references_tab_contents You may need to $\log$ in to JSTOR to access the linked references.

Your use of the JSTOR archive indicates your acceptance of the Terms \& Conditions of Use, available at http://about.jstor.org/terms

JSTOR is a not-for-profit service that helps scholars, researchers, and students discover, use, and build upon a wide range of content in a trusted digital archive. We use information technology and tools to increase productivity and facilitate new forms of scholarship. For more information about JSTOR, please contact support@jstor.org.

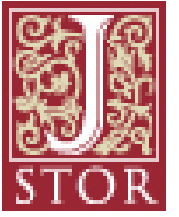

The University of Chicago Press, Bibliographical Society of America are collaborating with JSTOR to digitize, preserve and extend access to The Papers of the Bibliographical Society of America 


\title{
A Previously Unremarked Circulating Library: John Roson and the Role of Circulating-Library Proprietors as Publishers in Eighteenth-Century Britain ${ }^{1}$
}

\author{
EDWARD JACOBS
}

\section{$\mathrm{T}$}

HE entry in The Eighteenth-Century Short Title Catalogue on CD$R O M^{2}$ for The History of Miss Dorinda Catsby and Miss Emilia Faulkner (London: printed and sold by S. Bladon, 1772) notes that it contains between volumes one and two an advertisement for the catalog of John Roson's circulating library. However, Roson's library is not included in the lists of known English circulating libraries compiled by Hilda Hamlyn and by Paul Kaufman, ${ }^{3}$ and evidently no actual copy of a Roson catalog has survived. Still, merely the advertisement for this cata$\log$ tells us much about Roson's library business, and the discovery that he both ran a circulating library and published books makes him another illustration of the important but heretofore largely ignored role played

I. The research that made this essay possible was partially funded by an Old Dominion University Faculty Summer Research Fellowship for the Summer of 1993.

2. (London: British Library, 1992). Hereafter cited as ESTC.

3. In "The Circulating Libraries of the Eighteenth Century" (M. A. thesis: London University, 1948), pp. I06-I34, Hamlyn provides a comprehensive list, complete with authorities. In "The Community Library: A Chapter in English Social History," Transactions of the American Philosophical Society, n.s., 57 (1967): 3-67, p.53 Kaufman provides a supplemental list, but does not give citations for his authorities.

Edward Jacobs (Department of English, Old Dominon University, Norfolk, Va. 23529) is an assistant professor of English, teaching British literature, literary theory, and film studies. He has published articles on eighteenth- and nineteenth-century British literature and publishing history, and is currently finishing a book on the connections between historiographical and literary Gothicism in England.

PBSA 89:I (March 1995), pp. 6I-7I 
by circulating libraries in the publishing - as well as the distribution-of books in eighteenth-century Britain. ${ }^{4}$

Much in Roson's advertisement implies that his library did a strong business primarily by offering patrons new, popular books in octavo or duodecimo format. The first page of the advertisement, as it appears in the British Library's copy [126II.aa.6], is as follows:

\section{This Day is published, A New CATALOGUE OF THE \\ COLLECTION of BOOKS}

In J. Roson's Circulating Library in almost every Branch of Literature, which are lent to Read by the Year, Quarter, Month, or Single Book;

By JOHN ROSON, BOOKSELLER AND STATIONER, at No. 54, ST. MARTIN Le GRAND.

N.B. Great variety of New Books on Useful and Entertaining Subjects, will be added to the Library as soon as published.

** At the above Place is given full Value for any Library or Parcel of Books, and Books bought, sold, or exchanged.

Following this page are two pages of conditions, which generally conform to the standard conditions for this decade described by Hamlyn

4. The major studies of eighteenth-century British circulating libraries are Hamlyn and Kaufman (above, n.2); Hamlyn's "Eighteenth-Century Circulating Libraries in England," The Library, th $^{\text {th }}$ series, I (1947): 197-222 is a cogent summary of her thesis, although it does not contain the full bibliography offered by the thesis. See also Lee Erickson, "The Economy of Novel Reading: Jane Austen and the Circulating Library," Studies in English Literature, 1500-1900 30 (1990): 573-90; Jan Fergus, "Eighteenth-Century Readers in Provincial England: The Customers of Samuel Clay's Circulating Library and Bookshop in Warwick, 1770-2," PBSA 78 (1984): 155-213; Allan McKillop, "English Circulating Libraries, I725-50," The Library, 4th series, I4 (1934): 477-85; and Devendra Varma, The Evergreen Tree of Diabolical Knowledge (Washington: Consortium Press, 1972). James Raven, "The Noble Brothers and Popular Publishing, 1737-89," The Library 12 (1990): 293-345 is the only study of circulating-library publishers, per se, and is an invaluable model and source for future studies. In the course of my essay I have given notes indicating aspects of Roson's businesses that articulate with Raven's findings about the Noble brothers. 
and Kaufman, with rates being twelve shillings per year or four shillings per quarter. ${ }^{5}$ Rather unusually, however, Roson stipulates that these rates qualify patrons to withdraw only two books at a time, and that "No Subscriber [is] to have more than one New Book at a time, nor to keep it more than six days." Together with the above promise to buy new books "as soon as published," this later stipulation suggests that Roson dealt heavily in recent publications. A note on the final page of the advertisement in a similar way stresses to patrons that Roson's library will supply them almost exclusively with current, popular items: "N.B. As books in folio and quarto are generally considered as incommodious, and not fit for common use, the proprietor has purchased editions of such books as are most likely to be wanted, in order to accommodate every reader." In bibliographic and historical context, this emphasis could indicate that Roson stocked mainly octavo and duodecimo novels, since novels in these formats (and especially the latter) became a craze during the I770s precisely because they were less physically and financially "incommodious" than larger, more lavishly produced books. The fact that Roson advertised the catalog for his library between the volumes of a recent duodecimo novel also strongly suggests that his library targeted novel readers as patrons.

Given that we have no extant catalog, the actual proportion of novels held by Roson's library cannot be verified. But whatever percentage of new books and/or novels Roson did offer patrons, other peculiarities in the advertisement suggest that his business was just about as brisk as his stock of books could support. Besides limiting all subscribers to two borrowings at a time, and further restricting both the loan period and number of borrowings for new books, Roson's fourth condition advises patrons to send a "list of eight or ten titles," in order to "avoid disappointment." In this context, we might note that if Roson's stock of books was relatively small, then it is all the more likely that he did specialize in recent, popular works of fiction, since, according to Kaufman's survey of the percentage of fiction in extant circulating-library catalogs, libraries with smaller holdings contained a much higher proportion of fiction than larger libraries did. ${ }^{6}$

5. Hamlyn, "Eighteenth-Century Circulating Libraries in England," pp. 209-I2 is the best summary, but see also Kaufman, pp. I9 and 57 .

6. Kaufman, pp. I4-6; cf. Erickson, p. 580. 
Admittedly, unless an actual catalog for Roson's library is discovered, his advertisement for it must remain a rather enigmatic set of clues about the nature of his library business. However, the advertisement does document Roson as a circulating-library proprietor, and, like many circulating library proprietors, Roson also published books. Certainly he was far from being so prolific a publisher as major circulating-library publishers such as Thomas Lowndes, John and Francis Noble, Thomas Hookham, or William Lane. Still, ESTC lists Roson as being involved in the publication of thirty-four books, while Antonia Forster's Index to Book Reviews in England, $1749-1774^{7}$ documents his involvement in another title not indexed by ESTC. My own recovery of imprints for the fiction titles which are listed in circulating-library catalogues of Thomas Lowndes (I766) and M. Heavisides (I790), ${ }^{8}$ but which are not cataloged by ESTC, shows Roson to have been concerned in at least two other publications, imprints and physical information about which appear in the appendix to this article. ${ }^{9}$ In context of the stress laid by Roson's catalog advertisement on the recent, popular works that his circulating library offered patrons, it is significant that of these thirty-seven known books published by Roson, nineteen (5I percent) are duodecimo or octavo works of fiction, with the duodecimo works outnumbering octavo sixteen to three. Of the thirty-seven total books, twenty-three (62 percent) are duodecimo, twelve ( 32 percent) are octavo, and only two (6

7. (Carbondale: Southern Illinois University, 1990). The title is Memoirs of Francis Dillon, Esq.; In a Series of Letters written by bimself, 2 vols., (London: for T. Hookham and J. Roson, I772), a copy of which is held by The University of Chicago's Regenstein Library, but which ESTC cataloguers seem to have overlooked.

8. M. Heavisides, A Catalogue of Books, Instructive and Entertaining, which are to be lent out by M. Heavisides, Bookseller, Stationer, Bookbinder and Printer (Darlington: I790); Thomas Lowndes, A New Catalogue of Lowndes's Circulating Library (London: Lowndes, [1766]).

9. ESTC fails to catalog these two titles because it is a union-catalogue type database, and evidently no copies of these two books are housed by major libraries. But since these books manifestly were published and read during the eighteenth century, I have cited in the appendix their imprints as given by the eighteenth-century sources where I found those imprints. For each title I have also described any substantive information about the content or style of the work contained in the source(s) and given the number of the title in the catalog of M. Heavisides, whence I originally traced them, and in the 1794 catalog of Thomas Hookham, who was evidently involved in their publication, as I explain below. 


\section{The John Roson Circulating Library}

percent) are quarto. Evidently, as a publisher Roson specialized in precisely the recent, popular and, physically "commodious" books that his circulating library flourished before potential subscribers.

Aside from the fact that Roson published thirty-seven books and ran a circulating library, little is known about him, but the specific imprints for the three works not catalogued by ESTC shed some interesting light on his position as one of the many people who both published books and ran a circulating library during the last half of the eighteenth century. More specifically, these imprints suggest that roughly between I769 and 1772 Roson was part of a publishing network involving Samuel Bladon and Thomas Hookham. Cooperative publishing was of course not at all curious; it was in fact typical for relatively small publishers like Roson to join with others, and indeed Roson worked with no fewer than twenty other publishers, booksellers, and/or printers in publishing his thirtyseven known books. However, his interactions with Bladon and Hookham are especially interesting because, like Roson, Hookham was at the time of their cooperation a relative fledgling both as a publisher and as a circulating-library operator, whereas Bladon had been a publisher, printer, and bookseller in Paternoster Row since the early $1730{ }^{0} .{ }^{10}$ As is fairly well known, Hookham became the operator of one of the largest London circulating libraries during the last two decades of the eighteenth century and was also an important publisher, who among other achievements published the first three novels of Ann Radcliffe, including The Romance of the Forest (I79I), the work that first made her Gothic "terror" style a popular model for imitation. Yet because at the time of his involvement with Roson and Bladon, Hookham was like Roson only just establishing his businesses, this network illustrates how many circulating-library publishers were "upstart crows" scrambling to compete with the older, more highly capitalized houses. ${ }^{11}$ The specific kind of in-

Io. For the dates of Hookham's circulating-library career see the authorities in Appendix I of Hamlyn's "The Circulating Libraries of the Eighteenth Century"; for the dates of his publishing career, see Henry Plomer, A Dictionary of the Printers and Booksellers Who Were at Work in England Scotland and Ireland from 1726 to 1775 (London: Bibliographical Society, 1968). Plomer describes Bladon as a bookseller and publisher in Paternoster Row from I733 to I799, and cites Timperley's statement that he "was a skilled accountant and was frequently an arbitrator in complicated accounts" (27). However, the many imprints in ESTC that list books "printed by S. Bladon" imply that he also worked as a printer.

II. Cf. Raven, pp. 303-9. 
teraction that is implied by the imprints of the three books not catalogued by ESTC more specifically suggests that one way circulatinglibrary publishers competed was by presenting themselves to the public as a comprehensive kind of publishing institution that could at once finance, print, and circulate books offered them by prospective authors.

With respect to Bladon, the most curious evidence of commercial partnership with Roson is the fact that the catalog for Roson's circulating library is advertised in a book whose title pages describe it as "printed and sold by S. Bladon," rather than in one of the thirty-seven or more books that Roson himself published or cooperated in publishing. Moreover, among the fifteen books which Roson published in conjunction with others, ESTC lists one book printed "for Roson, and sold by S. Bladon and W. Goldsmith," one book printed "for" both Roson and Bladon, and one more "printed for Richardson and Urquhart; S. Bladon; and J. Roson." The evidence for Hookham's participation in the RosonBladon network involves some puzzling ambiguities in the imprints for the two "lost books" listed in my appendix and for the book cited by Forster but missed by ESTC. In The History of Miss Dorinda Catsby and Miss Emilia Faulkner (London: printed and sold by S. Bladon, 1772)the book in which Roson's catalog is advertised - there also appears a list of other books "lately printed and sold by S. Bladon." Among the books so listed are The Reward of Virtue; or the History of Miss Polly Graham and The Memoirs of Francis Dillon, Esq., the former of which is one of the lost books listed in my appendix, and the latter of which is the work found by Forster but missed by ESTC. However, the actual title pages of the University of Chicago's copy of Memoirs of Francis Dillon describe the book as "Printed for T. Hookham; and J. Roson," without mentioning Bladon at all. More confusingly yet, the Monthly Review gives "Hookham \&c." as the publishers of Memoirs of Francis Dillon, while the Critical Review mentions neither Hookham nor Bladon, listing only Roson as the publisher of this book. The ambiguities surrounding the publication of the two "lost books" in whose publication Roson was involved are less complex, if only because no known copy of either book has survived, and because both books were evidently reviewed only by the Monthly Review. ${ }^{12}$ Yet the ambiguities that do appear suggest that Bladon, Hookham, and Roson worked as members of a recognizable network. For instance, just as the Monthly Review listed "Hookham \&c." as the publishers of Mem-

I2. Forster, p. 245. 


\section{The John Roson Circulating Library}

oirs of Francis Dillon, it lists "Roson \&c." as the publishers of The Prudent Orphan: or the History of Miss Sophia Stanley, which is the other "lost book" besides The Reward of Virtue listed in my appendix. And while, as we have seen, the advertisement in The History of Miss Dorinda Catsby and Miss Emilia Faulkner promotes both Memoirs of Francis Dillon and The Reward of Virtue as "lately printed and sold by" Bladon, the Monthly Review lists Roson as publisher of The Reward of Virtue. Since Bladon evidently worked as an actual printer, and since the entries in eighteenth-century reviews typically list as "publisher" the first person given on a book's title page(s) as having had the book printed "for" them, this last ambiguity implies that Roson financed The Reward of Virtue, and that Bladon printed it "for" him and helped to sell it. By this logic, one might assume that Hookham and Roson jointly financed the publication of Memoirs of Francis Dillon and The Prudent Orphan, which were also printed and sold "by" Bladon "for" them.

Having offered this hypothesis, let me concede that the standard imprint phrases are known to represent myriad and subtle varieties of actual commercial relationship. Another logical alternative to the relation above is that Bladon, as an established publisher with a presumably strong capital reserve, both printed and helped to finance these books, but involved Hookham and Roson in the venture because their circulating libraries could help the books circulate and even sell. This supposition is strengthened by the fact that both Memoirs of Francis Dillon and the two "lost books" listed in the appendix appear in Hookham's 1794 catalog for his circulating library, ${ }_{13}^{13}$ as well as in the catalog of M. Heavisides whence I first traced them. ${ }^{14}$ The probability is strong that Roson's library also stocked these books, although we cannot know this for certain without a catalog. Whatever the actual business relation was between the three men, it is surely significant both that Hookham and Roson, at the beginnings of their careers, worked in some sort of cooperation with an experienced publisher known for his skill as an accountant, ${ }^{15}$ and that this unusually shrewd and experienced publisher should foresee advantage in joint ventures with two men who were fledgling publishers but who were also starting up circulating libraries. Cynically,

13. A New Catalogue of Hookhams' Circulating Library (London: Hookham, [1794]).

I4. Cf. Raven, pp. 313-4.

I5. Plomer, p.27. 
one might interpret the imprint contradictions between Bladon's book advertisements, the title page of Memoirs of Francis Dillon, and the reviews as evidence that Bladon was trying to "steal" credit from Hookham and Roson; by this reasoning, Bladon was concerned to maintain his public reputation as an established, independent publisher, against the appearance that he had become someone who published books "for" upstarts like Hookham and Roson. But if Bladon were out to distance himself from Hookham and Roson, then why did he let Roson advertise the catalog of his circulating library in the same book where Bladon tried to "steal" imprint credit from Roson? Rather than competing for public profile, Bladon, Hookham, and Roson would seem to have been cooperating in order to heighten their composite, communal profile as part of a network who could produce and market books from start to finish. From the perspective of the Roson's and Hookham's circulating library businesses, such a public profile would logically bolster patrons' confidence in the ability of the libraries to provide - indeed, to createnew books "as soon as published," which is precisely the ability most stressed by Roson's catalog advertisement. ${ }^{16}$ From the perspective of the three publishing businesses, this same profile might encourage prospective authors to bring their manuscripts to these publishers rather than to others, since the library adjuncts of these publishers provided a readymade "test market." 17 To an unprecedented extent, this network and ones like it could guarantee "circulation" for the books they published.

Significantly, the inventive, "point-of-contact" publicity used by this network to advertise their comprehensive abilities was typical of circulating libraries and the publishers associated with them. Raven remarks that " $[\mathrm{w}]$ hat distinguished the Nobles from their rivals was their shameless skill for self-advertisement," and moreover emphasizes that they gained this publicity essentially "[w]ithout undertaking the large and expensive full-column newspaper advertising that so occupied Longman, Dodsley, and Newberry." ${ }^{18}$ The remarkable ingenuity of circulating-library publicity is illustrated by Varma's third appendix to The Evergreen Tree of Diabolical Knowledge, which reproduces "Some Quaint,
16. Cf. Raven, pp. 312-3.
17. Cf. Raven, pp. 309-15.
I8. Raven, p.307. 


\section{The John Roson Circulating Library}

Queer, and Curious Advertisements." ${ }^{19}$ Unfortunately, heretofore very little analysis has been made of the precise image that circulating libraries tried to create with their advertisements. However, the work that has been done suggests that the style of much circulating-library publicity identified the libraries with popular modes of fiction such as "mysteries," and that this publicity also subtly but consistently invited reading patrons to try their hands as fledgling romancers and novelists. ${ }^{20}$ The Bladon-Hookham-Roson network is in this respect again typical of circulating-library publishers, since, as a form of publicity, their imprints and advertisements at once associated them with new, popular fiction, and made them especially attractive to novice authors as potential publishers.

Practically, the economic situation of circulating-library publishers like Roson and Hookham motivated them to be particularly interested both in finding and developing "new talent" for the novel market, and in joint financing. For as part of a second generation of fiction publishers who were trying to compete against established and more highly capitalized houses such as those surrounding Samuel Richardson, Millar, Tonson, and the Longmans and Robinsons, most circulating-library publishers - and especially fledgling ones - could not afford to buy the expensive copyrights to new works by established authors. Given this inability to compete for established authors, circulating-library publishers logically needed to attract and develop new talent in order to gain a market share. Roson's preference both as a librarian and publisher for recent, popular works in octavo and duodecimo would seem to illustrate this strategy, and even a cursory examination of the careers of the most significant "new talent" that emerged in the last two decades of the eighteenth century reveals the disproportionate role played by circulatinglibrary publishers as developers of the novel. Thus, for example, Frances Burney, Robert Bage, and Ann Radcliffe all broke into the novelwriting business with circulating-library publishers. With respect to Radcliffe, one might moreover remark that the Gothic romance genre

19. Varma, pp. 135-I44.

20. Edward Jacobs, "Unlearned Monsters: An Archaeology of the Gothic Romance" (Ph.D. diss., University of Illinois, 1990), 334-50ff; and "Anonymous Signatures: Circulating Libraries, Conventionality, and the Production of Gothic Romances," forthcoming in ELH. 
was almost entirely underwritten by circulating-library publishers. Thomas Lowndes published the fraudulent first edition of The Castle of Otranto, Hookham published the first three novels of Ann Radcliffe, and John Bell's family, if not John Bell himself, published Lewis's The Monk. ${ }^{21}$ By investing in these definitive experiments in the Gothic genre, circulating-library publishers effectively created a "craze" that would support them and many other publishers and authors for decades, and that culminated in William Lane's notorious Minerva Press, which churned out the genre originally sponsored by earlier circulating-library publishers. To track and analyze the actual instances of networking between these publishers through imprints and correspondence would be an enormous and complex task beyond the scope of this essay. However, the instances of John Roson and of the Noble brothers, together with the circumstantial evidence just outlined of a circulating-library network centered around the publishing and circulation of the Gothic romance genre, suggests that such an exhaustive analysis would not only confirm the important role circulating libraries played as publishers of innovative eighteenth-century fiction, but might also reveal the commercial ingenuity and cohesiveness of circulating-library publishers as a subculture within the British publishing world.

\section{APPENDIX}

Two Fiction Titles Published by John Roson Which Are Listed in the Circulating-library Catalogs of M. Heavisides (I790) and of Thomas Hookham (1794), And Which Are Not Included in ESTC, But for Which Imprints Have Been Located in Eighteenth-Century Reviews

The Prudent Orphan: or the History of Miss Sophia Stanley. (Heavisides \#597; Hookham \#3255). I20 2 vols 5s. Roson \&c. (Monthly Review April 1775). Contains no substantive information, aside from the observation that "some fair readers may learn from it, that gypsies are not such ignorant creatures as the wise folk represent them, but may be very successfully consulted on certain great occasions; and that all a young lady has to do, to render herself perfectly agreeable, is to take a lesson once a day, or

2I. Hamlyn, "Eighteenth-Century Circulating Libraries in England," p. 202. 
oftener if she finds it necessary, from Miss Sophia, Miss Harriot, Miss Charlotte, or some other accomplished fair (to be met with at any of the circulating libraries) on the wonderful art and mystery of love."

The Reward of Virtue; or the History of Miss Polly Graham. Intermixed with several curious and interesting Incidents in the Lives of several Persons of both Sexes, remarkable for the singular Adventures which befel them. To which is added, a brief Description of Bounty-Hall, and its Inhabitants. (Heavisides \#619; Hookham \#3272). 120 2s 6d. Bladon (Advertisement in The History of Miss Dorinda Catsby and Miss Emilia Faulkner [Bladon, 1772]) / Roson (Montbly Review December 1769). "A jumble of improbable and ill-connected tales." 